\title{
PEMBAHARUAN HUKUM PENANGGUNGAN : STUDI PERBANDINGAN DENGAN HUKUM PENANGGUNGAN (BORGTOCHT) DI BELANDA
}

\author{
THE LEGAL REFORM OF SURETYSHIP : A COMPARATIVE STUDY \\ WITH SURETYSHIP (BORGTOCHT) IN NETHERLANDS
}

\author{
Susanti \\ Notaris Susanti \\ Email : notaris_susanti@yahoo.com
}

Naskah diterima : 05/11/2018; direvisi : 20/12/2018; disetujui : 26/12/2018

\begin{abstract}
Abstrak
Jaminan perorangan atau yang lebih dikenal dengan penanggungan diatur dalam Buku 3 Bab 17 Pasal 1820 sampai dengan 1850 Burgelijk Wetboek (BW). BW yang menjadi landasan hukum penanggungan dirasakan belum dapat memberi perlindungan hukum bagi penanggung. Pembaharuan hukum penanggungan sangat diperlukan untuk dapat memberikan perlindungan hukum bagi penanggung, terutama yang berkaitan dengan pengaturan hak-hak penanggung. Metode yang digunakan dalam kajian ini adalah metode penelitian hukum normatif. Perbandingan hukum khususnya secara micro dilakukan dengan memperbandingkan aturan hukum mengenai penanggungan yang berlaku di Indonesia (BW) dengan penanggungan (borgtocht) yang berlaku di Belanda (Nieuw Burgelijk Wetboek (NBW)). Tujuan yang hendak dicapai dalam penelitian ini adalah untuk menemukan persamaan dan perbedaan dengan pengaturan hukum penanggungan di Belanda, yang kemudian dapat dijadikan sebagai pedoman untuk pembaharuan hukum penanggungan di Indonesia.
\end{abstract}

Kata kunci : Penanggungan, Pembaharuan Hukum, Perbandingan Hukum, Burgelijk Wetboek, Nieuw Burgelijk Wetboek.

\begin{abstract}
The personal guarantee or known as suretyship regulated in Book 3 Chapter 17 Article 1820 to 1850 Burgelijk Wetboek (BW). BW which is the legal basis considered unable to provide legal protection for surety. The legal reform of suretyship is severely needed to provide legal protection for surety, especially for the one related to the regulation of rights for surety. The method used in this study is normative legal research. The comparative law, especially in micro was carried out by comparing the rule of law on suretyship applicable in Indonesia $(B W)$ to the one applicable in Netherlands (Niew Borgelijk Wetboek (NBW). The purpose achieved in this study is to find out the similarities and differences in the legal arrangement of suretyship in Netherlands which can be used as a guideline for the legal reform of suretyship in Indonesia.
\end{abstract}

Keywords: Surety-ship, Legal Reform, Comparative Law, Burgelijk Wetboek, Nieuw Burgelijk Wetboek. 


\section{PENDAHULUAN}

Jaminan perorangan atau yang lebih dikenal dengan penanggungan merupakan salah satu bentuk jaminan yang sering dipersyaratkan dalam penyaluran kredit perbankan. Penanggungan merupakan suatu perjanjian dengan mana seorang pihak ketiga, guna kepentingan si berpiutang, mengikatkan diri untuk memenuhi perikatan si berutang manakala orang ini sendiri tidak memenuhinya. Penanggungan diatur dalam Buku 3 Bab 17 Pasal 1820 sampai dengan 1850 Burgerlijk Wetboek (untuk selanjutnya disebut BW).

BW yang menjadi landasan hukum penanggungan dirasa belum dapat memberikan perlindungan hukum bagi penanggung. Salah satunya adalah mengenai pengaturan hakhak yang dimiliki oleh penanggung. Penanggung dalam menjalankan perannya, diberikan hak-hak oleh undang-undang yang bertujuan untuk memberikan perlindungan baginya. Namun di sisi lain, undang-undang juga memberikan kebebasan kepada penanggung untuk melepaskan hak-hak tersebut.

Praktiknya, celah hukum ini sering digunakan dalam perjanjian penanggungan, di mana senantiasa diadakan janji yang tegas agar penanggung melepaskan hak-hak yang dimilikinya demi kepentingan kreditor. Janji untuk melepaskan hak-hak penanggung dapat dikatakan sebagai kebiasaan yang senantiasa diperjanjikan atau "bestendig gebruikelijk beding" sebagaimana dimaksud dalam Pasal 1347 BW. ${ }^{1}$

Pelepasan hak-hak yang dimiliki oleh penanggung didasarkan pada ketentuan Pasal 1338 (1) BW, yang memberikan kebebasan seluas-luasnya kepada para pihak untuk mengadakan perjanjian yang berisi apa saja, sepanjang tidak melanggar ketertiban umum dan kesusilaan, yang kemudian dikenal dengan prinsip kebebasan berkontrak (freedom of contract). ${ }^{2}$

Pelepasan hak-hak yang dilakukan oleh penanggung membawa akibat hukum manakala debitor wanprestasi, yaitu kreditor dapat secara langsung meminta pelunasan atas utang-utang debitor kepada penanggung. Dengan demikian kedudukan penanggung menjadi sama dengan debitor.

Pembaharuan hukum penanggungan sangat diperlukan untuk dapat memberikan perlindungan hukum bagi penanggung, terutama yang berkaitan dengan pengaturan hak-hak yang diberikan oleh undang-undang kepada penanggung. Salah satu upaya pembaharuan hukum penanggungan dapat dilakukan dengan melakukan perbandingan hukum. Perbandingan hukum dalam bahasa asing, diterjemahkan: Comparative Law (bahasa Inggris) dan Rechtsvergelijking (bahasa Belanda).

Konrad Zweigert dan Hein Kötz menilai Comparative Law sebagai "An intellectual activity with law as its object and comparison as its process." 3 Dalam melakukan perbandingan hukum selalu ada tujuan yang ingin dicapai oleh comparatist. Secara umum Konrad Zweigert dan Hein Kötz mengatakan bahwa "The primary aim of comparative law, as of all sciences, is knowledge". "Secara khusus, L.J.Van Apeldoorn, menjabarkan tujuan perbandingan hukum dapat dibedakan antara tujuan teoritis dan tujuan yang bersifat praktis.

\footnotetext{
${ }^{1}$ Sri Soedewi Majchon Sofwan, Hukum Jaminan Di Indonesia Pokok-Pokok Hukum Jaminan Dan Jaminan Perorangan, Liberty, Cet. I, Yogyakarta, 1980, hlm 93.

${ }^{2}$ Muhammad Arifin, Penyalahgunaan Keadaan Sebagai Faktor Pembatas Kebebasan Berkontrak, Jurnal Ilmu Hukum, Vol. 14, No. 2, Edisi September 2011, hlm. 277.

${ }^{3}$ Konrad Zweigert dan Hein Kötz, Introduction to Comparative Law, Cet III, (terjemahan Tony Weir), Oxford University Press, Oxford, 1988, hlm. 2.

${ }^{4}$ Ibid, hlm. 15.
} 
Tujuan yang bersifat teoritis menjelaskan bahwa hukum sebagai gejala dunia (universiil) dan oleh karena itu ilmu pengetahuan hukum harus dapat memahami gejala dunia tersebut dan untuk itu kita harus memahami hukum di masa lampau dan pada masa sekarang. Tujuan yang bersifat praktis dari perbandingan hukum adalah merupakan alat pertolongan untuk tertib masyarakat dan pembaharuan tentang berbagai peraturan dan pikiran hukum kepada pembentuk undang-undang dan hakim. ${ }^{5}$

Perbandingan hukum pada dasarnya dapat dilakukan dengan 2 (dua) cara, yaitu memperbandingkan secara makro dan mikro. Istilah perbandingan makro dan perbandingan mikro pertama kali dicetuskan oleh Max Rheinstein. ${ }^{6}$ Menurut Max Rheinstein, micro comparisons adalah "Comparison between topics or institutions of two or more legal systems", sedangkan macro comparisons adalah "Comparison between two or more entire legal systems". Perbandingan hukum baik secara makro maupun mikro,dilakukan tidak hanya untuk menemukan persamaan dan perbedaan tetapi juga untuk menjelaskan penyebab persamaan dan perbedaan serta untuk menentukan suatu solusi. $^{7}$

Perbandingan hukum dalam penelitian ini adalah perbandingan hukum secara micro yang dilakukan dengan memperbandingkan aturan hukum mengenai penanggungan yang berlaku di Indonesia dengan yang berlaku di Belanda, terutama yang berkaitan dengan pengaturan hak-hak yang dimiliki oleh penanggung. Dalam hal ini studi perbandingan hukum dijatuhkan pada negara Belanda, karena selain memiliki sistem hukum yang sama yaitu Civil Law, Nieuw Burgelijk Wetboek (untuk selanjutnya disingkat NBW) yang berlaku di Belanda merupakan perkembangan dari BW yang hingga kini masih diberlakukan di Indonesia.

Penelitian ini menggunakan metode penelitian hukum normatif. Dari uraian latar belakang di atas penulis ingin menemukan persamaan dan perbedaan dengan pengaturan hukum penanggungan di Belanda, terutama yang berkaitan dengan pengaturan hakhak penanggung, yang kemudian dapat dijadikan sebagai pedoman untuk pembaharuan hukum penanggungan di Indonesia.

\section{PEMBAHASAN}

\section{Hukum Penanggungan Di Indonesia}

Pengaturan hukum penanggungan di Indonesia belum mengalami perubahan sejak BW dikodifikasi, yaitu tanggal 1 Januari 1848. Perjanjian penanggungan di Indonesia diatur dalam Buku 3 Bab 17 Pasal 1820 sampai dengan pasal 1850 BW. Berdasarkan ketentuan pasal $1820 \mathrm{BW}$, penanggungan adalah suatu perjanjian dengan mana seorang pihak ketiga, guna kepentingan si berpiutang, mengikatkan diri untuk memenuhi perikatan si berutang manakala orang ini sendiri tidak memenuhinya.

Penanggungan merupakan perjanjian yang bersifat accessoir dimana eksistensi atau adanya penanggungan itu tergantung dari adanya suatu perjanjian pokok, yaitu perjanjian yang pemenuhannya ditanggung atau dijamin dengan perjanjian penanggungan. Dalam perjanjian penanggungan, penanggung tidak dapat mengikatkan diri untuk lebih, maupun dengan syarat-syarat yang lebih berat daripada perikatan

\footnotetext{
${ }^{5}$ Romli Atmasasmita, Asas-asas Perbandingan Hukum Pidana, Yayasan Lembaga Hukum Indonesia, Jakarta,1989, hlm. 29 .

${ }^{6}$ Peter de Cruz, Perbandingan Sistem Hukum Common Law, Civil Law, Dan Socialist Law, Cet III, (terjemahan Narulita Yusron), Nusa Media, Bandung, 2012, hlm. 325.

${ }^{7}$ D. Kokkini-Iatridou, Some Methodological Aspects of Comparative Law, Netherlands International Law Review, Vol 33, 1986, hlm. 155.
} 
debitor. Jika penanggungan diadakan untuk lebih dari utangnya, atau dengan syaratsyarat yang lebih berat, maka perikatan tersebut tidak menjadi batal, melainkan sah hanya untuk apa yang diliputi oleh perikatan pokoknya. ${ }^{8}$

Penanggungan selain bersifat accessoir, jika ditinjau dari sudut cara pemenuhannya bersifat subsidair. Peranan penanggung baru muncul setelah debitor utama tidak memenuhi kewajiban perikatannya. Pemenuhan oleh penanggung bersifat sebagai pengganti apa yang ditinggalkan debitor utama tidak terpenuhi, sekalipun sebagaimana yang umum terjadi sisa kewajiban debitor utama yang dipenuhi oleh penanggung diwujudkan dalam bentuk ganti rugi sejumlah uang. Dalam pembayaran ganti rugi sejumlah uang tampak sifat subsidair daripada penanggungan. ${ }^{9}$

Perjanjian penanggungan pada asasnya bentuknya bebas, dalam arti dapat diberikan secara lisan maupun tertulis. Dalam pemberian penanggungan, yang khas bukannya isi prestasi para pihak, tetapi suatu unsur formal tertentu, yaitu bahwa penanggung menjamin pelaksanaan prestasi orang lain. Konsekuensinya, isi prestasinya bisa macammacam, bergantung dari apa yang berdasarkan perikatan pokok dijamin, ditinggalkan debitur tidak dipenuhi atau berupa janji ganti rugi senilai itu. ${ }^{10}$ Prestasi debitor utama yang pasti dapat diberikan oleh penanggung adalah kalau kewajiban itu berupa menyerahkan sejumlah uang tertentu.

Pada asasnya dalam perjanjian penanggungan, si penanggung itu hanya mengikatkan diri untuk pemenuhan sejumlah uang. Ini merupakan bentuk yang lazim dalam perjanjian penanggungan. Seandainya penanggungan itu diberikan untuk perutangan yang tidak berwujud dalam jumlah uang, maka jika kreditor menuntut pemenuhan dari penanggung, harus dapat diwujudkan dalam bentuk uang. ${ }^{11}$

Dalam hal debitor utama wanprestasi, penanggung tidak hanya wajib untuk memenuhi kewajiban perikatan debitor utama, tetapi juga wajib memberikan ganti rugi yang ditimbulkan oleh wanprestasinya debitor utama. Sebelum menjalankan perannya, penanggung mempunyai hak-hak yang diberikan oleh undang-undang yang bersifat memberikan perlindungan baginya yang terdiri dari hak umum dan hak utama. ${ }^{12}$

Hak umum penanggung diatur dalam pasal 1847 B.W. yang berbunyi: " Si penanggung utang dapat menggunakan terhadap si berpiutang segala tangkisan yang dapat dipakai oleh si berutang utama dan mengenai utangnya yang ditanggung itu sendiri. Namun tak bolehlah ia mengajukan tangkisan-tangkisan yang melulu mengenai pribadi si berutang". Maksud ketentuan tersebut adalah penanggung dalam menjalankan kewajibannya mempunyai hak untuk mengajukan tangkisan-tangkisan yang dapat dipakai oleh debitor terhadap kreditor, kecuali tangkisan yang berkaitan dengan pribadi debitor. Penggunaan hak tersebut tidak bergantung dari debitor, meskipun debitor tidak menggunakan hak tersebut, namun penanggung tetap dapat menggunakannya.

\footnotetext{
${ }^{8}$ Ketentuan pasal 1822 BW merupakan konsekwensi logis dari sifatnya penanggungan sebagai perjanjian accessoir. Perikatan-perikatan dalam suatu perjanjian yang sifatnya "mengabdi" kepada suatu perjanjian pokok, tidak bisa melebihi perikatan-perikatan yang diterbitkan oleh perjanjian pokok itu. Lihat Subekti, Aneka Perjanjian, Cet. VIIII, PT. Citra Aditya Bakti, Bandung, 1996, hlm.165.

${ }^{9}$ J. Satrio, Hukum Jaminan, Hak-Hak Jaminan Pribadi Tentang Perjanjian Penanggungan Dan Perikatan Tanggung Menanggung, PT. Citra Aditya Bakti, Bandung, 1996, hlm. 53.

${ }_{10}$ Ibid., hlm.11.

${ }^{11}$ Namun sebagai pengecualian, dalam perjanjian penanggungan juga dimungkinkan bahwa si penanggung tidak menanggung pemenuhan pembayaran sejumlah uang, melainkan penanggung dipenuhinya suatu prestasi. Misalnya menanggung menyelesaikan pekerjaan, hal demikian kita jumpai dalam bentuk penanggungan pembangunan. Juga dapat menanggung melakukan perbaikan-perbaikan pada rumah sewaan, manakala pihak yang berwajib tidak dapat memenuhi prestasi tersebut. Periksa Sri Soedewi Majchon Sofwan, Op. Cit., hlm.86.

${ }^{12}$ J. Satrio, Op. Cit., hlm. 48.
} 
Mengenai hak utama penanggung tercantum dalam pasal 1831 B.W yang berbunyi : "Si penanggung tidaklah diwajibkan membayar kepada si berpiutang, selain jika si berutang lalai, sedangkan benda-benda si berutang ini harus lebih dahulu disita dan dijual untuk melunasi utangnya." Dari ketentuan tersebut, manakala penanggung digugat di depan pengadilan untuk memenuhi kewajiban debitor utama yang telah wanprestasi, penanggung dapat menangkis dengan mengemukakan eksepsi, agar harta kekayaan debitor utama dieksekusi terlebih dahulu untuk diambil sebagai pelunasan (voorrecht van eerdere uitwinning) untuk selanjutnya disebut hak tuntut "ambil pelunasan dari debitor lebih dahulu". ${ }^{13}$ Penanggung dapat menggunakan ataupun tidak menggunakan hak tersebut, yang pasti hak tersebut harus dikemukakan dan tidak berjalan secara otomatis (Pasal 1833 B.W). Namun menurut ketentuan 1832 BW, hak utama "ambil pelunasan dari debitor lebih dahulu" tidak dapat digunakan oleh penanggung dalam keadaan:

- Penanggung telah secara sukarela melepaskan hak utama tersebut

- Penanggung telah mengikatkan diri bersama-sama dengan debitor utama sebagai debitor tanggung-menanggung kepada kreditor

- Jikalau debitor utama dapat mengajukan tangkisan yang hanya mengenai pribadi debitor utama sendiri

- Jikalau debitor utama pailit

- Jikalau terdapat penanggungan yang diperintahkan hakim.

Dalam hal terdapat lebih dari seorang penanggung yang bersama-sama memberikan jaminan penanggungan untuk kepentingan dan utang seorang debitor yang sama serta untuk keuntungan kreditor yang sama pula, ketika kreditor menuntut seluruh prestasi yang terutang oleh debitor, penanggung dapat menangkis dengan minta agar kreditor memecah/membagi utang debitor utama diantara para penanggung, dan mengurangi sampai sebesar bagiannya (menurut perbandingan sesuai dengan perjanjiannya). Hak tersebut biasa disebut hak utama untuk menuntut pemecahan hutang. ${ }^{14}$

Prakteknya, baik hak umum maupun hak-hak utama yang dimiliki penanggung, dalam perjanjian penanggungan senantiasa diadakan janji yang tegas untuk dilepaskan demi kepentingan kreditor. Dengan melepaskan hak-hak utamanya, maka tiap-tiap penanggung sekarang dapat langsung ditagih oleh kreditor untuk seluruh hutang debitor utama, tanpa keharusan adanya upaya kreditor untuk mengambil pelunasan lebih dahulu dari debitor utama dan sekalipun ada lebih dari seorang penanggung yang menjamin perikatan yang sama tersebut. ${ }^{15}$ Hal ini dikarenakan, penanggung yang melepaskan hak-hak utamanya mempunyai konsekuensi kedudukan disamping sebagai penanggung juga sebagai debitur tanggung-menanggung.

Pembayaran yang telah dilakukan penanggung atas apa yang terutang oleh debitor utama terhadap kreditor, membuat penanggung mempunyai hak untuk menuntut kembali dari debitor utama. ${ }^{16}$ Hak untuk menuntut pembayaran kembali dari debitor utama dikenal pula dengan istilah hak regres. Penanggung hanya mempunyai hak regres untuk sebesar yang telah dibayarkan olehnya meliputi uang pokok, bunga dan biayabiaya. ${ }^{17}$

Pada ketentuan pasal 1840 BW, undang-undang memberikan hak subrogatie kepada penanggung yang telah membayar utang debitor utama. Dalam peristiwa demikian,

\footnotetext{
${ }^{13}$ Ibid., hlm. 114.

${ }^{14}$ Ibid., hlm. 123.

${ }^{15}$ Ibid., hlm. 134.

${ }^{16}$ Pasal 1839 ayat (1) BW.

${ }^{17}$ Pasal 1839 ayat (2) BW.
} 
penanggung berkedudukan sebagai pihak ketiga yang membayar dan subrogatie ini terjadi demi undang-undang, dalam arti terjadi secara otomatis, tanpa diperjanjikan lebih dahulu (pasal 1400 jo pasal 1402 sub 3). ${ }^{18}$ Subrogatie hanya memberikan penggantian hak sebesar pembayaran penanggung kepada kreditor dan karenanya ganti rugi dan biaya perkara tidak termasuk di dalamnya. Dengan demikian, penanggung yang telah membayar utang debitor utama kepada kreditor, diberikan dua sarana untuk mengambil kembali pembayaran yang telah ia lakukan, yaitu melalui hak regres dan subrogatie. Sekalipun keduanya sama-sama dimaksudkan sebagai sarana mengambil kembali pembayaran penanggung, tetapi penggunaan masing-masing sarana mempunyai akibat hukumnya masing-masing, dengan segala keuntungan dan kerugiannya. ${ }^{19}$

\section{Hukum Penanggungan (Borgtocht) Di Belanda}

Penanggungan dalam bahasa asing diterjemahkan: Suretyship ${ }^{20}$ (bahasa Inggris) atau Borgtocht ${ }^{21}$ (bahasa Belanda), sedangkan penanggung diterjemahkan: Surety (bahasa Inggris) atau Borg (bahasa Belanda). Di Belanda, pengaturan mengenai Borgtocht berpusat pada NBW yang pada tahun 1992 pertama kali diundangkan dan menggantikan seluruh Civil Code lama yang telah ada sejak tahun 1838. Borgtocht merupakan special contract yang diatur dalam Buku 7 Bab 14 Pasal 850 sampai dengan Pasal 870 NBW. Pengertian borgtocht tercantum dalam pasal 850 ayat (1) NBW, yang dalam bahasa Belanda dan terjemahannya bahasa Inggris berbunyi sebagai berikut : ${ }^{22}$

"Borgtocht is de overeenkomst waarbij de ene partij, de borg, zich tegenover de andere partij, de schuldeiser, verbindt tot nakoming van een verbintenis, die een derde, de hoofdschuldenaar, tegenover de schuldeiser heeft of zal krijgen."

(Suretyship is a contract whereby one party, the surety, obliges himself towards the other party, the obligee, to perform an obligation to which a third person, the principal obligor, is or will be bound towards the oblige.)

Dari pengertian Borgtocht atau Suretyship tersebut di atas, terdapat pihak-pihak yang mempunyai kepentingan, yaitu the obligee (untuk selanjutnya disebut kreditor ${ }^{23}$ ) dan surety $^{24}$ selaku penjamin dari the principal obligor (untuk selanjutnya disebut debitor utama $^{25}$ ). Di mana kreditor mempunyai kepentingan terhadap kepastian pengembalian kredit yang ia berikan kepada debitor utama, sedangkan Surety biasanya didasarkan pada kepentingan tertentu atau adanya hubungan khusus dengan debitor utama.

\footnotetext{
${ }^{18}$ J. Satrio, Op. Cit., hlm.173.

${ }_{19}$ Perlu diingat, bahwa borg hanya gesubrogeerd sebesar pembayarannya, kalau ia membayar separoh hutang debitur-utama, maka ia pun hanya gesubrogeerd untuk separoh hak-hak kreditor. Dalam hal demikian, maka berlakulah ketentuan pasal 1403, sehingga kalau borg membayar sebagian saja dari hutang debitur-utama, ada unsur yang kurang menguntungkan, seperti yang disebutkan dalam pasal 1403 dan karenanya perlu mendapat perhatian sebelum memutuskan untuk memilih menggunakan hak regres atau subrogatie, kecuali kalau borg menggunakan kedua-dua sarana itu. Periksa J. Satrio, Op. Cit., hlm.176.

20 "The suretyship is a special form of guarantee arrangement which comprises three parties: one person (the surety) acts as surety for second person's (the principle debtor's) obligation to a third person (the creditor). Lihat Aurelia Colombi Ciacchi dan Stephen Weatherill, Regulating Unfair Banking Practices In Europe: The Case Of Personal Suretyships, Oxford University Press, Oxford, 2010, hlm. 8.

${ }_{21}$ Ibid., hlm.416. The borgtocht is the personal suretyship contract that has been codified under the Dutch Civil Code (Burgerlijk Wetboek, hereinafter B.W.).

${ }^{22}$ The Civil Code of the Netherlands Antilles and Aruba, (terjemahan Peter Haanappel et al.), Kluwe Law International, Netherlands, 2002, hlm. 437.

${ }^{23}$ Aurelia Colombi Ciacchi dan Stephen Weatherill, Op Cit., hlm.415 : A Creditor is a person who has a (contractual) claim against another person, commonly as a lender under a credit facility.

${ }^{24}$ A Surety is a person who undertakes to pay money or to do any other act in event that his principal fails there in. Periksa Bryan A. Garner, Black's Law Dictionary, ninth edition, West Publishing CO, United States of America, 2009, hlm.1293.

${ }^{25}$ Aurelia Colombi Ciacchi dan Stephen Weatherill, Loc Cit. A Debtor is a person who has an obligation (s) against the creditor, commonly as a borrower under a contract of loan.
} 
Perjanjian Suretyship merupakan perjanjian accessoir, di mana keberlakuan perjanjian Suretyship bergantung pada perjanjian pokok yaitu perjanjian antara kreditor dengan debitor. Meskipun perjanjian pokok dan Suretyship merupakan dua perjanjian yang berbeda, namun berkaitan erat satu sama lain. Hal ini dapat dilihat dari dua debitor yang berbeda namun mempunyai kewajiban utang kepada kreditor yang sama. Yang satu merupakan debitor yang ditanggung (debitor utama), sedangkan yang satunya merupakan debitor dalam perjanjian penanggungan (surety).

Menurut CJ Pretorius dan JT Pretorius ${ }^{26}$ : "The liability that the Surety undertakes is an accessory obligation." Prinsip accessoir ini tercermin dalam pasal 851 ayat (1) NBW yang berbunyi : "Suretyship is dependent upon the obligation of the principal obligor only to the extent that they are sufficiently determinable"27 dan pasal 853 NBW yang berbunyi : "Suretyship is extinguished on expiry of the period of prescription of the right of action to claim performance of the obligation by the principal obligor."28

Selain prinsip accessoir, perjanjian Suretyship juga mengandung prinsip subsidair sebagaimana tercermin dalam pasal 855 ayat (1) NBW yang berbunyi: "The surety is not obliged to perform until such time as the principal obligor has failed in the performance of his obligation." $" 29$

Ciri-ciri khusus sebagaimana yang dimiliki oleh suretyship/borgtocht tersebut di atas lah yang membedakan borgtocht dengan personal guarantees lainnya ${ }^{30}$, karena "Personal guarantees other than borgtocht contracts, on the other hand, do not in this way depend on the contractual obligations they guarantee. These guarantees are analysed as "independent" contracts which may be enforced irrespective of the obligation(s) they secure." 31

Di negara Belanda, Suretyship sering diberikan sebagai jaminan atas pembiayaan/ fasilitas kredit yang disalurkan oleh kreditor kepada debitor. ${ }^{32}$ Pemberian Suretyship tersebut dapat dilakukan baik dengan sepengetahuan debitor maupun tanpa sepengetahuan debitor, karena "The validity of suretyship does not require that the principal obligor is aware of it" $"$.

Pemberian Suretyship pada dasarnya mempunyai tujuan untuk menjamin kepastian pengembalian kredit, manakala debitor wanprestasi. JT Pretorius ${ }^{34}$, berpendapat bahwa : "The Surety has one obligation only, to perform or pay in the debtor's place should the debtor fail to perform". Dalam hal perjanjian pokoknya bukan mengenai pembayaran sejumlah uang, maka pemberian Suretyship bertujuan untuk membayar kerugian yang diderita oleh kreditor sebagai akibat dari tidak dilakukannya suatu kewajiban oleh debitor. ${ }^{35}$

\footnotetext{
${ }^{26}$ CJ Pretorius dan JT Pretorius, Failed Suspensive Conditions and the Law of Suretyship : Some Basic Principles-Firstrand Bank Ltd V Meyer, Journal of Contemporary Roman-Dutch Law, Vol 79, 2016, hlm. 156.

${ }^{27}$ The Civil Code of the Netherlands Antilles and Aruba, Op Cit., hlm.438.

${ }^{28}$ Ibid., hlm.439.

${ }^{29}$ Ibid.

${ }^{30}$ Aurelia Colombi Ciacchi dan Stephen Weatherill, Op Cit., hlm.416. Personal Guarantees lainnya, contohnya repurchase commitments (terugkoopverklaring). Under such a contract, A guarantees to repurchase the asset (s) he sold to $B$, should $B$ fail to pay his (finance) debt to $C$. B then does not receive the purchase moneys, because they are paid to $C$. This type of contract does not qualify as borgtocht, because under a borgtocht contract, the guarantor guarantees to fulfil the same obligation that the debtor owes.

${ }_{31}$ The Civil Code of the Netherlands Antilles and Aruba, Loc Cit.

32 Aurelia Colombi Ciacchi dan Stephen Weatherill, Op Cit., hlm.419:"Although exact figures are not available, it is generally agreed that personal guarantees continue to play an important role in the credit facility industry in the Netherlands. Certain assets, such as cars, caravans, and the like, are commonly financed on the basis of borgtocht contract."

${ }^{33}$ Pasal 850 ayat (2) NBW.

${ }^{34}$ JT Pretorius, Unlimited Suretyships, Journal of Contemporary Roman-Dutch Law, Vol 75, 2012, hlm. 188.

${ }_{35}$ Pasal 854 NBW: Unless explicitly stipulated otherwise, where the object of the obligation of the principal obligor is not the payment of a sum og money, the suretyship is for the claim for damages due for non-performance of such obligation.
} 
Pemberian Suretyship tidak harus dibuat secara tertulis, kecuali jika surety merupakan non-professional. ${ }^{36}$ Dalam hal Suretyship diberikan oleh non-professional, maka akan berlaku ketentuan Buku 7 Bab 14 Bagian 2 Pasal 857 sampai dengan Pasal 864 NBW. Dalam Pasal 857 NBW dikatakan bahwa, "The provisions of this Section apply to suretyship entered into by a natural person acting neither in the conduct of a profession or business, nor for a benefit of the normal exploitation of the business of a company limited by shares or privat limited liability company of which he is a director and in which, alone or with his codirector, he holds a majority of the shares." ${ }^{37}$ Ketentuan-ketentuan tersebut secara khusus dirancang untuk melindungi surety yang masuk ke dalam personal suretyship contract dalam kapasitas non-professional.

Surety yang masuk ke dalam personal suretyship contract dalam kapasitas nonprofessional dikategorikan sebagai Consumers ${ }^{38}$ Suretyship Contract, sedangkan Surety yang masuk ke dalam personal suretyship contract dalam kapasitas professional ${ }^{39}$ dikategorikan sebagai Commercial Suretyship Contract.

Seorang Surety dapat mengikatkan dirinya untuk menjamin kewajiban-kewajiban debitor yang akan datang selama jumlahnya telah ditentukan. ${ }^{40}$ Jika pada waktu Consumers Suretyship Contract dibuat dan jumlah kewajiban debitor masih belum ditentukan, maka perjanjian suretyship hanya berlaku untuk jumlah maksimum kewajiban yang telah ditentukan dalam bentuk uang yang telah disepakati bersama. ${ }^{41}$ Namun, terhadap bunga dan biaya yang berkaitan dengan pasal $856 \mathrm{NBW}^{42}$ dapat diklaim tanpa memperhatikan jumlah maksimum tersebut di atas. ${ }^{43}$

Consumers Suretyship Contract yang diberikan untuk menjamin kewajiban-kewajiban debitor yang akan datang dapat berakhir sewaktu-waktu, jika tidak ditentukan jangka waktunya dan dapat berakhir setelah 5 (lima) tahun, jika telah ditentukan jangka waktunya. ${ }^{44}$ Walaupun jangka waktu Suretyship berakhir, Suretyship tetap berlaku untuk menanggung kewajiban yang telah timbul. ${ }^{45}$ Namun, surety tidak terikat untuk mengganti kerugian yang timbul sebagai akibat dari perbuatan debitor, manakala kreditur sendiri seharusnya dapat memperkirakan dan mencegah terjadinya kerugian tersebut dengan melakukan pengawasan. ${ }^{46}$

Surety juga tidak terikat pada kewajiban debitor yang akan datang, manakala kreditor telah melakukan suatu perbuatan yang tidak seharusnya dilakukan, setelah dia mengetahui keadaan di mana kemungkinan untuk melakukan jalan lain kepada debitor jauh berkurang, kecuali penjamin telah menyetujui secara eksplisit tindakan hukum semacam itu atau tindakan hukum tersebut tidak dapat ditunda lagi. ${ }^{47}$

\footnotetext{
${ }^{36}$ Pasal 859 NBW.

${ }^{37}$ The Civil Code of the Netherlands Antilles and Aruba, Op Cit., hlm.440

${ }^{38}$ Arts 6:236, 6:237, and art 7:5(1) NBW : Definition of "consumer" accords with the definition of consumer in other parts of Dutch private law, such as the Civil Code provisions regarding consumer rights under contractual general terms and conditions, and consumer sales law.

${ }_{39}$ Tidak termasuk dalam klasifikasi sebagaimana diatur dalam Pasal 857 NBW.

${ }^{40}$ Pasal 851 ayat (2) NBW: Suretyship can be entered into for future obligations of the principal obligor only to the extent that they are sufficiently determinable.

${ }^{41}$ Pasal 858 ayat (1) NBW.

${ }^{42}$ Pasal 856 ayat 1 NBW : "Legal interest shall be due by the surety only during the period that he is in default, unless the principal obligor is in default pursuant to article 83, subparagraph b of Book 6."

Pasal 7:856 ayat 2 NBW : "The surety must reimburse the costs of the judicial proceedings against the principal obligor if, by timely notice of the intention to bring action, he was given the opportunity to avoid such costs."

${ }^{43}$ pasal 7:858 ayat (2) NBW.

${ }^{44}$ Pasal 7:861 ayat (1) NBW.

${ }^{45}$ Pasal 7:861 ayat (2) NBW.

${ }^{46}$ Pasal 7:861 ayat (3) NBW.

${ }^{47}$ Pasal 7:861 ayat (4) NBW.
} 
Dalammenjalankanperannya, Surety tidakmempunyaikewajibanuntukmelaksanakan suatu prestasi sampai suatu waktu tertentu di mana debitor telah gagal melaksanakan kewajibannya. ${ }^{48}$ Manakala debitor telah gagal melaksanakan kewajibannya, maka kreditor wajib memberitahu hal tersebut kepada Surety. ${ }^{49}$ Namun, Surety tidak akan terikat atau menanggung kewajiban yang lebih berat daripada kewajiban debitor, kecuali dalam hal keberadaan dan luasnya kewajiban debitor tersebut dapat dibuktikan kepada surety. ${ }^{50}$ Dalam Suretyship diberlakukan pula ketentuan-ketentuan umum yang berkaitan dengan kewajiban tanggung-menanggung, sebagaimana diatur dalam buku 7 Bab 14 Pasal 850 ayat (3) yang berbunyi : "The provisions regarding solidary (joint and several) obligation apply to suretyship, save as otherwise provided in this Title".

Dalam menjalankan perannya, undang-undang memberikan hak kepada Surety yang bersifat memberi perlindungan kepadanya. Hak-hak tersebut tertuang dalam pasal 852 NBW antara lain : ${ }^{51}$

1. The surety may also avail himself of the defences which the principal obligor has against the obligee if they relate to the existence, content or time of performance of the obligation of the principal obligor.

2. If the principal obligor is entitled to invoke a ground of nullification to nullify the juridical act from which the obligation arises and if the surety of the obligee has given him a reasonable period to exercise that right, the surety is entitled to suspend the performance of his obligation during that period.

3. As long as the principal obligor properly suspends performance of his obligation towards the obligee, the surety is also entitled to suspend performance of his obligation.

Berdasarkan ketentuan Pasal 862 NBW menegaskan bahwa tidak boleh ada penyimpangan yang merugikan surety dari ketentuan Pasal 852 sampai dengan Pasal 856 dan Pasal 858 sampai dengan Pasal 861 NBW. Dengan kata lain, dalam perjanjian surety tidak boleh dilakukan pengecualian terhadap pasal-pasal tersebut. Dalam hal surety telah melaksanakan kewajibannya, maka akan berlaku ketentuan Pasal 866 ayat 1 NBW. Berdasarkan pasal 10 buku ke 6 NBW, surety dapat menuntut pembayaran dari debitor untuk seluruh utang pokok, bunga, dan biaya-biaya yang telah ia bayar kepada kreditor. Namun dengan pembatasan sebagaimana diatur dalam pasal 866 ayat (2) NBW yang berbunyi : "The surety cannot derive a claim against the principal obligor from article 10 of Book 6, nor from article 12 of that Book for legal interest over the period in which he has been in default by circumstances personal to him, or for costs which are personal to him or which he did not reasonably have to incur." 52

Manakala surety memberikan jaminan bagi dua atau lebih debitor (tanggung menanggung), maka tanpa memperhatikan pasal 10 ayat 1 , pasal 12 ayat 1 dari buku ke 6 NBW, para debitor (tanggung menanggung) bertanggung jawab secara bersamasama terhadap apa yang telah dibayarkan oleh surety baik utang pokok, bunga, dan biaya-biaya. ${ }^{53}$ Dalam hal surety telah melaksanakan kewajibannya tanpa memberitahu

\footnotetext{
${ }^{48}$ Pasal 855 ayat (1) NBW.

${ }^{49}$ Pasal 855 ayat (2) NBW.

${ }^{50}$ Pasal 860 NBW : The surety is not bound to the extent that his surety obligation is subject to more burdensome terms and conditions than those under which the principal debtor is bound by the secured obligation, except as far as these terms and conditions concern the way in which the existence and extent of the secured obligation of the principal debtor can be proven against the surety.

${ }_{51}$ The Civil Code of the Netherlands Antilles and Aruba, Op. Cit., hlm. 438.

${ }^{52}$ The Civil Code of the Netherlands Antilles and Aruba, Op. Cit., hlm.444.

${ }^{53}$ Pasal 866 ayat (3) NBW.
} 
debitor, dan oleh karenanya debitor juga telah membayar kreditor, maka debitor dapat meminta kreditor untuk mengembalikan pembayaran yang telah dilakukannya. ${ }^{54}$

\section{Persamaan dan Perbedaan Hukum Penanggungan (Borgtocht) di Indonesia dan Belanda}

Dalam perbandingan hukum penanggungan (borgtocht) di Indonesia dan Belanda, ditemukan persamaan dan perbedaan pengaturan antara di BW dan NBW. Persamaan pengaturan mengenai hukum penanggungan antara di BW dan NBW, yaitu:

a. Borgtocht/Suretyship mengandung prinsip accessoir dan subsidair.

b. Borgtocht/Suretyship dapat diberikan tanpa sepengetahuan debitor.

c. Ketentuan-ketentuan umum yang berkaitan dengan kewajiban tanggung-menanggung diberlakukan dalam Borgtocht/Suretyship.

d. Kewajiban Borg/Surety terbit setelah debitor utama wanprestasi.

e. Borg/Surety berkewajiban untuk melakukan pembayaran utang pokok, bunga dan biaya-biaya lainnya.

f. Borg/Surety tidak dapat mengikatkan diri untuk lebih, maupun dengan syarat-syarat yang lebih berat dari perikatan debitor.

g. Borg/Surety mempunyai hak regres dan hak subrogasi.

Sedangkan perbedaan pengaturan mengenai hukum penanggungan antara di BW dan NBW, yaitu:

a. Dalam BW tidak terdapat pengkategorian borg/surety, sedangkan dalam NBW terdapat pengkategorian antara borg/surety yang professional (commercial suretyship contract) dengan yang non-profesional (consumers suretyship contract).

b. Dalam BW Borgtocht/Suretyship dapat dibuat secara tertulis ataupun lisan, sedangkan dalam NBW Borgtocht/Suretyshipyang profesional dapat dibuat secara tertulis ataupun lisan dan untuk Borgtocht/Suretyship yang non-profesional harus dibuat secara tertulis.

c. Dalam BW hak-hak yang dimiliki borg/surety dapat diperjanjikan untuk dilepas, sedangkan dalam NBW hak-hak yang dimiliki borg/surety oleh undang-undang tidak boleh diperjanjikan untuk dilepas.

\section{SIMPULAN}

Dari hasil perbandingan hukum penanggungan (borgtocht) dengan negara Belanda, selain ditemukan beberapa persamaan juga ditemukan beberapa perbedaan, salah satunya mengenai pengaturan hak-hak yang dimiliki oleh penanggung. Dalam NBW, hak-hak yang diberikan oleh undang-undang kepada penanggung sebagaimana tercantum dalam Pasal 852 NBW tidak dapat dikesampingkan/dilepaskan. Hal tersebut ditegaskan dalam ketentuan Pasal 862 NBW. Pelarangan terhadap pengesampingan/ pelepasan hak-hak yang dimiliki penanggung tersebut sebagai bentuk perlindungan hukum yang diberikan oleh undang-undang kepada penanggung. Pelarangan terhadap pengesampingan/pelepasan hak-hak yang dimiliki penanggung dapat dijadikan sebagai salah satu pedoman untuk pembaharuan hukum penanggungan di Indonesia, sehingga tercipta perlindungan hukum terhadap penanggung.

\section{DAFTAR PUSTAKA}

\section{Buku-Buku}

Aurelia Colombi Ciacchi dan Stephen Weatherill, 2010, Regulating Unfair Banking Practices In Europe: The Case Of Personal Suretyships, Oxford University Press,

\footnotetext{
${ }^{54}$ Pasal 867 NBW.
} 
Oxford.

Bryan A Garner, 2009, Black's Law Dictionary, ninth edition, West Publishing CO, United States of America.

J. Satrio, 1996, Hukum Jaminan, Hak-Hak Jaminan Pribadi Tentang Perjanjian Penanggungan Dan Perikatan Tanggung Menanggung, PT. Citra Aditya Bakti, Bandung.

Konrad Zweigert dan Hein Kötz, 1988, Introduction to Comparative Law, Cet III, (terjemahan Tony Weir), Oxford University Press, Oxford.

Peter de Cruz, 2012, Perbandingan Sistem Hukum Common Law, Civil Law, Dan Socialist Law, Cet III, (terjemahan Narulita Yusron), Nusa Media, Bandung.

Peter Haanappel, et al., 2002, The Civil Code of the Netherlands Antilles and Aruba, Kluwe Law International, Netherlands,

Romli Atmasasmita, 1989, Asas-asas Perbandingan Hukum Pidana, Yayasan Lembaga Hukum Indonesia, Jakarta.

Sri Soedewi Majchon Sofwan, 1980, Hukum Jaminan Di Indonesia Pokok-Pokok Hukum Jaminan Dan Jaminan Perorangan, Cet. I, Liberty, Yogyakarta.

Subekti, 1996, Aneka Perjanjian, Cet. VIIII, PT. Citra Aditya Bakti, Bandung.

Peraturan Perundang-undangan

Kitab Undang-Undang Hukum Perdata (Burgelijk Wetboek), Staatsblad Nomor 23 Tahun 1847.

\section{Peraturan Lainnya}

Nieuw Nederlands Burgerlijk Wetboek (Boek 7).

\section{Jurnal}

CJ Pretorius dan JT Pretorius, 2016, Failed Suspensive Conditions and the Law of Suretyship : Some Basic Principles-Firstrand Bank Ltd V Meyer, Journal of Contemporary Roman-Dutch Law, Vol 79.

D. Kokkini Iatridou, 1986, Some Methodological Aspects of Comparative Law, Netherlands International Law Review, Vol 33.

JT Pretorius, 2012, Unlimited Suretyships, Journal of Contemporary Roman-Dutch Law, Vol 75.

Muhammad Arifin, 2011, Penyalahgunaan Keadaan Sebagai Faktor Pembatas Kebebasan Berkontrak, Jurnal Ilmu Hukum, Vol. 14, No. 2, Edisi September. 